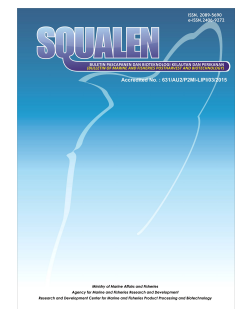

\title{
Quality of Refrigerated Tilapia (Oreochromis niloticus) Slices under Vacuum and Modified Atmosphere Packaging
}

\author{
Md. Abdul Karim, Masudur Rahman, Esmout Jahan Alice, Md. Amanullah, Md. Akhtar \\ Hossain and Md. Tariqul Islam* \\ Department of Fisheries, University of Rajshahi, Rajshahi 6205, Bangladesh \\ Article history: \\ Received: 30 July 2020; Revised: 30 October 2020; Accepted: 1 December 2020
}

\begin{abstract}
In order to develop a proper packaging system for sliced tilapia fish (Oreochromis niloticus), the biochemical and microbiological qualities under control (unsealed package), vacuum package and modified atmosphere packaging with $50 \% \mathrm{CO}_{2} / 50 \% \mathrm{~N}_{2}$ (MAP-1) and $50 \% \mathrm{CO}_{2} / 50 \% \mathrm{O}_{2}$ (MAP-2) were evaluated every three days during 18 days of chilled storage $\left(4 \pm 1^{\circ} \mathrm{C}\right)$. The $\mathrm{pH}$ value was not significantly different $(p>0.05)$ by treatments until day 9 , but significantly lower values $(p<0.05)$ were observed on day 12 of the storage in all treated samples compared to the control. The total volatile base nitrogen (TVB-N) value progressively increased, but not significantly different $(p>$ 0.05 ) in all treatments during the entire storage period. The thiobarbituric acid reactive substances (TBARS) amounts were significantly lower $(p<0.05)$ on day 12 in the vacuum and MAP-1 samples compared to the control sample, and were significantly higher $(p<0.05)$ on day 6,9 , and 12 of the storage period in MAP-2 samples compared to the control, vacuum and MAP-1 samples. The amounts of $\mathrm{pH}$, TVB-N, and TBARS in all samples did not exceed the acceptable limit in almost the entire storage. The total viable count (TVC) progressively increased with storage time. Nevertheless, TVC values were lower $(p<0.05)$ on day 6,9 , and 12 of the storage periods in all treatments compared to the control. The TVCs exceeded the acceptable limit ( $7 \mathrm{log}$ CFU/g) on days 6-9 for control, 9-12 for vacuum, day 12 for MAP-2, and 15 for MAP-1 sample during the storage period. Therefore, the MAP has shown promising results for shelf life extension that can be practiced to display the fishery products with prolonged shelf life.
\end{abstract}

Keywords: Tilapia, vacuum packaging, modified atmosphere packaging, quality, shelf life

\section{Introduction}

Tilapia (Oreochromis niloticus) is a freshwater fish commonly known as Nile Tilapia under the family of Cichlidae. Tilapia is native to Africa, and later it has been widely introduced for culture into tropical, subtropical, and even in temperate countries. It is a fast-growing species and has become the second most common farm-raised fish in the world (Gupta \& Acosta, 2004). This fish is a popular cultured fish since it supports high-density culture system, resist hard environmental stress, tolerates low oxygen concentration, and is suitable for pond and cage cultures (DeLong, Losordo, \& Rakocy, 2009). It contains several biochemical compositions in human diets. The proximate composition of tilapia fillets is moisture $77.6 \%$, proteins $19.5 \%$, total lipids $2 \%$, and ash $1.8 \%$ on a wet basis (Bogard et al., 2015). The protein of tilapia is complete because it contains all essential amino acids. The omega- 3 fatty acid is also found in tilapia muscle (Gonzales \& Brown, 2006). It is regarded as a vitamin-rich fish containing vitamins A, D, E, B1, B3, B5, B6, B12, ascorbic acid, and folic acid. Several minerals are found in the tilapia fish body, including zinc, iron, iodine, calcium, selenium, magnesium, sodium, phosphorus, manganese, potassium, copper, sulfur, and chromium (Gonzales \& Brown, 2006; Bogard et al., 2015).

With changing lifestyles, the buying behavior of the customers is also changed. The root causes of this change are economic development and social status. Nowadays, city-dwellers seek ready-to-cook

${ }^{*}$ Corresponding author.

E-mail: tariqrubd@gmail.com 
or semi-prepared foods instead of raw foods due to their busy life. There are no such fish products available in the market of developing countries, including Bangladesh (Amanullah, 2019). To fulfill this demand, the superstores of the country could play an important role. However, the short shelf life is a limiting factor for perishable items like fish, even under the refrigerated condition in the superstores (Ashie, Smith, \& Simpson, 1996). Extension of shelf life is significantly beneficial for the fish processing industries, as it can minimize the losses occurred at the stages of distribution and display. Some modern methods are developed for preserving the fish by technologists to fulfill the consumer demand for fresh fish with a reasonable price (Nagarajarao, 2016). In this respect, the packaging technology is receiving growing attention. Vacuum packaging and modified atmosphere packaging (MAP) are receiving increasing attention as preservation methods along with refrigerated storage to prolong the shelf life of fresh fish and meat (Narasimha Rao \& Sachindra, 2002).

In case of MAP, various gases such as $\mathrm{N}_{2}, \mathrm{CO}_{2}$, $\mathrm{O}_{2}$, and $\mathrm{CO}$ have been used. Among these, $\mathrm{CO}_{2}$, perhaps the most commonly used and effective gas along with other gases (DeWitt \& Oliveira, 2016). Carbon dioxide is soluble in both water and lipids. It has a significant role as a bacteriostatic effect in MAP technology. It reduces the growth of microorganisms at the log phase (Alfaro, Hernández, Le Marc, \& Pin, 2013). However, the effects are varied with $\mathrm{CO}_{2}$ concentration, microbial load, storage temperature, and the type of packaged product (DeWitt \& Oliveira, 2016). On the other hand, oxygen is used in MAP technology to prevent the growth of exclusively anaerobic bacteria and the toxin production by Clostridium botulinum type E (Pantazi, Papavergou, Pournis, Kontominas, \& Savvaidis, 2008). Oxygen is also used to avoid the discoloration of the flesh (Soccol \& Oetterer, 2003). Therefore, the application of MAP technology has become more popular with increasing consumer awareness and public demand (Sveinsdóttir, Martinsdóttir, Hyldig, \& Sigurgísladóttir, 2010).

The MAP has been widely used as a packaging technique to extend the shelf life up to $25-400 \%$ of fish, meat, and various products in developed countries (DeWitt \& Oliveira, 2016). The extension of shelf life in a vacuum packaging and MAP depends on raw materials, gas mixtures, temperature, and packaging materials. This packaging has been studied mostly for marine fishes (Ruiz-Capillas \& Moral, 2001; DeWitt \& Oliveira, 2016). However, not many studies were found on MAP for freshwater fishes such as tilapia, sutchi catfish, and carps (Li et al., 2017; Masniyom, Benjama, \& Maneesri, 2013; Noseda et al., 2012). This form of packaging has not yet evolved in the market of developing countries, i.e., Bangladesh. Therefore, the current study was aimed to develop a proper vacuum packaging and MAP for this tilapia fish to extend the shelf life, which can ensure the supply of quality fishes conveniently.

\section{Material and Methods}

\subsection{Sample Collection and Preparation}

Fifty tilapia fishes (Oreochromis niloticus) with the individual weight of $0.5 \pm 0.1 \mathrm{~kg}$ were brought from a farmer in Puthia Upazila, Rajshahi - Bangladesh. The fish samples were transported in live condition to the Quality Control Laboratory of the Department of Fisheries, Rajshahi University. Then fishes were stunned by a percussive method and killed by cutting the head portions (Lines \& Spence, 2012). Then fishes were dressed and cut into small slices with an average weight of $100 \pm 10 \mathrm{~g}$. Fish slices were washed twice with running tap water at room temperature $\left(25^{\circ} \mathrm{C}\right)$, and the last wash was performed with distilled water. After washing, all fish slices were kept in ice to preserve the freshness until packaging.

\subsection{Packaging and Storage of Sample}

Fish slices weighing approximately $200 \mathrm{~g}$ were placed in plastic pouches having high gas and moisture barrier properties. The multi-layered transparent pouch (polyethylene/polyamide/ polyethylene) having $100 \mu \mathrm{m}$ densities was used for this purpose (Premiaflex Plastics Ltd., Dhaka). Four packaging systems were prepared as follow: (1) unsealed package as control; (2) vacuum package as treatment-1; (3) MAP-1 $\left(50 \% \mathrm{CO}_{2} / 50 \% \mathrm{~N}_{2}\right)$ as treatment-2 and (4) MAP-2 $\left(50 \% \mathrm{CO}_{2} / 50 \% \mathrm{O}_{2}\right)$ as treatment-3. Vacuum packaging and MAP were carried out by the Multivac packaging unit (C100, Haggenmuller, Germany) fitted with a Gas Mixer (KM100-3 MEM, WITT, Germany) as instructed in the manual. After packaging, the amount of $\mathrm{O}_{2}, \mathrm{~N}_{2}$, and $\mathrm{CO}_{2}$ gas were randomly monitored in the headspace of some of the packaged samples by a gas analyzer (Oxybaby M+, WITT, Germany) to ensure whether the gas ratio was correct. Packaged samples were preserved at $4 \pm 1^{\circ} \mathrm{C}$ in a refrigerator (GL-C322RLBBPZ, LG, South Korea) for 18 days. Three samples of each treatment were taken every three days for analysis in the laboratory.

\subsection{Biochemical and Microbiological Analyses}

Various microbiological and biochemical analyses were performed to determine the shelf life of sliced tilapia fish stored at refrigerated temperatures. $A 10 \mathrm{~g}$ 
of cut fish flesh was homogenized upon adding $50 \mathrm{~mL}$ of distilled water and then the $\mathrm{pH}$ of the homogenate was determined by a pH meter (HI2002, Hanna Inst, USA) (Binsi et al., 2015). Total volatile base nitrogen (TVB-N) was measured following European Commission (2005) method. According to Park et al. (2007), thiobarbituric acid reactive substance (TBARS) was estimated using the colorimetric method. Total viable count (TVC) was determined on plate count agar (Sigma-Aldrich, USA) by standard pour plate method following the decimal dilution technique by American Public Health Association (APHA) (1992) and expressed as log colony-forming units (log CFU/g). Plates were kept for $48 \mathrm{~h}$ in an incubator (Poleko, Poland) at $35^{\circ} \mathrm{C}$, and later colonies were counted. The total coliforms and total fecal coliforms were enumerated by the method described by Food and Drug Administration (FDA) (2002) using nine tubes, the most probable number (MPN) test. In this case, only one sample from each packaging system was performed.

\subsection{Statistical Analysis}

All experiments were performed in triplicate. Data were subjected to analysis using one-way ANOVA. Tukey test was performed to measure the significant differences $(p<0.05)$ among treatments. Statistical analysis was conducted using the program SPSS Version 20 (IBM, IL, US).

\section{Results and Discussion}

\section{1. $\mathrm{pH}$ Value}

$\mathrm{pH}$ is an indicator factor for assessing the quality of fish and fishery products. The appropriate post mortem pH level is typically 6.8 7.0 (Metin, Erkan, Varlik, \& Aran, 2001). In this study, the initial $\mathrm{pH}$ values of freshly sliced tilapia was 6.79. High initial $\mathrm{pH}$ values followed by declines were found for some treatments, and later increasing trends were evident. Nevertheless, until day 9 of the storage period, the $\mathrm{pH}$ values $(p>$ $0.05)$ were not significantly affected by the treatments (Table 1$)$. Significantly $(p<0.05)$ lower $\mathrm{pH}$ values were found in all treatments as compared to the control group on day 12 of the storage period. Similarly, no significant variations in $\mathrm{pH}$ values were observed under different packaging systems (air, vacuum, and MAP) at $1^{\circ} \mathrm{C}$ for tilapia fish (Cyprian et al., 2013) and at $4^{\circ} \mathrm{C}$ for rohu fish (Das, Alice, Hossain, Mehbub, \& Islam, 2020). In another study, significantly no differences in $\mathrm{pH}$ values were observed for ready-to-cook (RTC) pangas curry among the treatments (unsealed package, MAP-1 with $50 \% \mathrm{CO}_{2} / 50 \% \mathrm{~N}_{2}$, and MAP-2 with $75 \% \mathrm{CO}_{2} / 25 \% \mathrm{~N}_{2}$ ) at $4{ }^{\circ} \mathrm{C}$ during storage (Nayma, Das, Alice, Mehbub, \& Islam, 2020). Lactic acid production via anaerobic glycolysis and the release of inorganic phosphates as a result of ATP degradation seemed to be the main reasons for this initial decreased $\mathrm{pH}$ values (Ayala et al., 2010). In 22 days of ice preservation, Ayala et al. (2010) have observed a similar trend of results for sea bream. On the other hand, the reaction between $\mathrm{CO}_{2}$ and water forming carbonic acid that creates an acidic condition in the fillets may explain this decreasing $\mathrm{pH}$ (Velu, Abu Bakar, Mahyudin, Saari, \& Zaman, 2013). pH value reached the acceptable limit on days 9-12 for the control, day $12-15$ for vacuum, and day 18 of the storage period for MAP-2 sample (Table 1). Increased $\mathrm{pH}$ at the later storage stage could be due to the accumulation of amines and other volatile compounds through the autolytic and microbial activity on proteins and other compounds (Binsi, Shamasundar, \& Dileep, 2007).

Table 1. pH value of sliced tilapia (Oreochromis niloticus) under vacuum packaging and MAP systems during storage at $4 \pm 1^{\circ} \mathrm{C}$

\begin{tabular}{|c|c|c|c|c|c|c|c|}
\hline \multirow{2}{*}{ Treatments } & \multicolumn{6}{|c|}{ Storage Period (days) } & \multirow[b]{2}{*}{18} \\
\hline & 0 & 3 & 6 & 9 & 12 & 15 & \\
\hline $\begin{array}{l}\text { Unsealed } \\
\text { package (Control) }\end{array}$ & $6.59 \pm 0.05^{\mathrm{a}}$ & $6.64 \pm 0.18^{a}$ & $6.53 \pm 0.40^{\mathrm{a}}$ & $6.78 \pm 0.10^{\mathrm{a}}$ & $7.39 \pm 0.1^{b}$ & & \\
\hline Vacuum package & $6.59 \pm 0.05^{\mathrm{a}}$ & $6.70 \pm 0.17^{a}$ & $6.74 \pm 0.27^{a}$ & $6.54 \pm 0.43^{\mathrm{a}}$ & $6.88 \pm 0.16^{a}$ & $7.09 \pm 0.21$ & \\
\hline $\begin{array}{l}\text { MAP-1 }(50 \% \\
\left.\mathrm{CO}_{2} / 50 \% \mathrm{~N}_{2}\right)\end{array}$ & $6.59 \pm 0.05^{a}$ & $6.43 \pm 0.09^{a}$ & $6.47 \pm 0.15^{\mathrm{a}}$ & $6.61 \pm 0.09^{a}$ & $6.72 \pm 0.08^{a}$ & $6.46 \pm 0.07$ & $6.80 \pm 0.06$ \\
\hline $\begin{array}{l}\text { MAP-2 }(50 \% \\
\left.\mathrm{CO}_{2} / 50 \% \mathrm{O}_{2}\right)\end{array}$ & $6.59 \pm 0.05^{\mathrm{a}}$ & $6.56 \pm 0.09^{a}$ & $6.33 \pm 0.23^{a}$ & $6.18 \pm 0.07^{a}$ & $6.67 \pm 0.01^{\mathrm{a}}$ & $6.81 \pm 0.18$ & $7.00 \pm 0.04$ \\
\hline
\end{tabular}

Values $(n=3)$ are expressed as mean \pm SD. The values in the same column with various superscript letters reflect the significant difference at $p<0.05$. 


\subsection{Total Volatile Base Nitrogen (TVB-N) Value}

In general, the chemical degradation of food is estimated by measuring changes in TVB- $N$ content, which is the sum of all chemicals including trimethylamine, dimethylamine, and ammonia. It is commonly used as an indicator for predicting bacterial spoilage of fish (Wu \& Bechtel, 2008). The TVB-N amount is generally considered to be an acceptability limit for ice-stored fish at $30-35 \mathrm{mg} \mathrm{N} / 100 \mathrm{~g}$ fish (Connell, 1995).

In the current study, the TVB-N content was initially $1.68 \pm 0.40 \mathrm{mg} / 100 \mathrm{~g}$ and then progressively increased over time for the whole storage period in all samples. The maximum TVB-N content reached $7.56 \pm 1.98 \mathrm{mg} /$ $100 \mathrm{~g}$ on day 12 of the storage for the control sample (Table 2). Increasing TVB-N value in refrigerated storage could be due to the production of basic compounds via microbiological action on protein and non-protein nitrogenous compounds. On and after 9 days of storage, the TVB-N rise becomes apparent when $\mathrm{pH}$ values were also comparatively higher. This condition might be correlated with deaminase activity in which favored under alkaline medium (Soccol, Oetterer, Gallo, Spoto, \& Biato, 2005). However, the increase in TVB-N contents of all packaged samples did not exceed the acceptable limit (30-35 mg/100g) (Table 2). Similarly, TVB-N values did not cross the acceptable limit in the case of sliced rohu fish (Das et al., 2020) and goonch fish (Bagarius bagarius) (Alice, Amanullah, Karim, Hossain, \& Islam, 2020) under the same packaging and storage conditions. During storage, the MAP samples are likely to have lower TVB-N content than the control and vacuum pack samples. TVB-N content was not significantly influenced $(p>0.05)$ by treatments during each of the storage days (Table 2). Soccol et al. (2005) found similar results with no significant differences in TVB$\mathrm{N}$ contents of tilapia fish among treatments (air package, vacuum package, and a MAP with $60 \% \mathrm{CO}_{2} /$ $40 \% \mathrm{O}_{2}$ ) during 20 days storage at $1^{\circ} \mathrm{C}$. Significantly higher levels of TVB-N content (more than $30 \mathrm{mg} / 100$ g) were observed in tilapia fish under air, vacuum and MAP $\left(60 \% \mathrm{CO}_{2}, 10 \% \mathrm{O}_{2} \& 30 \% \mathrm{~N}_{2}\right)$ at the end of 18 days of storage at $4^{\circ} \mathrm{C}$ (Masniyom et al., 2013) compared with the current study.

\subsection{Thiobarbituric Acid Reactive Substance (TBARS) Value}

TBARS is an important parameter for measuring secondary lipid oxidation products, including malonaldehyde (MDA). TBARS content of $2 \mathrm{mg}$ of $\mathrm{MDA} / \mathrm{kg}$ fish is the acceptable limit, and an unpleasant odor and taste have emerged in fish beyond this limit (Connell, 1995). In this study, the TBARS amount was initially $0.26 \mathrm{mg} \mathrm{MDA} / \mathrm{kg}$ tilapia fish. The TBARS amounts remained nearly steady, with some fluctuation for vacuum and MAP-1 samples over the entire storage period. On the other hand, TBARS amounts gradually increased until day 3 for MAP-2 and day 9 for the control sample and rose sharply in the rest of the storage. The TBARS amounts were significantly $(p<0.05)$ influenced by treatments in the storage period. The TBARS amounts of the vacuum and MAP-1 $\left(50 \% \mathrm{CO}_{2} / 50 \% \mathrm{~N}_{2}\right)$ samples were lower at the end of the storage than the control and MAP-2 samples (Table 3). A similar trend of TBARS value was observed for sliced goonch fish under the same packaging and storage conditions (Alice et al., 2020). It has possibly occurred for the absence of $\mathrm{O}_{2}$, which delayed the oxidation of the polyunsaturated fatty acids (PUFA). This finding is agreed with Masniyom

Table 2. TVB-N value ( $\mathrm{mg} / 100 \mathrm{~g}$ ) of sliced tilapia (Oreochromis niloticus) under vacuum packaging and MAP systems during storage at $4 \pm 1^{\circ} \mathrm{C}$

\begin{tabular}{|c|c|c|c|c|c|c|c|}
\hline \multirow{2}{*}{ Treatments } & \multicolumn{6}{|c|}{ Storage Period (days) } & \multirow[b]{2}{*}{18} \\
\hline & 0 & 3 & 6 & 9 & 12 & 15 & \\
\hline $\begin{array}{l}\text { Unsealed package } \\
\text { (Control) }\end{array}$ & $1.68 \pm 0.40^{\mathrm{a}}$ & $2.24 \pm 0.40^{\mathrm{a}}$ & $3.50 \pm 0.99^{a}$ & $4.76 \pm 0.40^{\mathrm{a}}$ & $7.56 \pm 1.98^{\mathrm{a}}$ & & \\
\hline Vacuum package & $1.68 \pm 0.40^{\mathrm{a}}$ & $2.80 \pm 0.00^{\mathrm{a}}$ & $3.64 \pm 0.40^{\mathrm{a}}$ & $5.88 \pm 0.40^{\mathrm{a}}$ & $6.44 \pm 0.20^{\mathrm{a}}$ & $7.14 \pm 0.20$ & \\
\hline $\begin{array}{l}\text { MAP-1 }\left(50 \% \mathrm{CO}_{2} /\right. \\
\left.50 \% \mathrm{~N}_{2}\right)\end{array}$ & $1.68 \pm 0.40^{\mathrm{a}}$ & $2.10 \pm 0.59^{a}$ & $3.36 \pm 0.00^{\mathrm{a}}$ & $2.66 \pm 0.59^{\mathrm{a}}$ & $5.04 \pm 0.40^{\mathrm{a}}$ & $5.32 \pm 0.40$ & $6.10 \pm 0.48$ \\
\hline $\begin{array}{l}\text { MAP-2 }\left(50 \% \mathrm{CO}_{2} /\right. \\
\left.50 \% \mathrm{O}_{2}\right)\end{array}$ & $1.68 \pm 0.40^{\mathrm{a}}$ & $2.24 \pm 0.00^{\mathrm{a}}$ & $3.22 \pm 0.20^{\mathrm{a}}$ & $3.80 \pm 0.62^{\mathrm{a}}$ & $4.70 \pm 1.27^{\mathrm{a}}$ & $6.10 \pm 0.68$ & $5.74 \pm 0.99$ \\
\hline
\end{tabular}

Values $(n=3)$ are expressed as mean \pm SD. The values in the same column with various superscript letters reflect the significant difference at $p<0.05$. 
Table 3. TBARS value (mg MDA/kg) of sliced tilapia (Oreochromis niloticus) under vacuum packaging and MAP systems during storage at $4 \pm 1^{\circ} \mathrm{C}$

\begin{tabular}{|c|c|c|c|c|c|c|c|}
\hline \multirow{2}{*}{ Treatments } & \multicolumn{6}{|c|}{ Storage Period (days) } & \multirow[b]{2}{*}{18} \\
\hline & 0 & 3 & 6 & 9 & 12 & 15 & \\
\hline $\begin{array}{l}\text { Unsealed package } \\
\text { (Control) }\end{array}$ & $0.26 \pm 0.08^{a}$ & $0.28 \pm 0.0^{\mathrm{a}}$ & $0.46 \pm 0.19^{\mathrm{ab}}$ & $0.62 \pm 0.08^{\mathrm{a}}$ & $1.59 \pm 0.03^{b}$ & & \\
\hline Vacuum package & $0.26 \pm 0.08^{a}$ & $0.30 \pm 0.03$ & $0.29 \pm 0.08^{a}$ & $0.60 \pm 0.05^{a}$ & $0.41 \pm 0.09^{a}$ & $0.71 \pm 0.07$ & \\
\hline $\begin{array}{l}\text { MAP-1 }\left(50 \% \mathrm{CO}_{2} /\right. \\
\left.50 \% \mathrm{~N}_{2}\right)\end{array}$ & $0.26 \pm 0.08^{a}$ & $0.36 \pm 0.01^{a}$ & $0.53 \pm 0.17^{\mathrm{ab}}$ & $0.53 \pm 0.03^{a}$ & $0.52 \pm 0.15^{a}$ & $0.77 \pm 0.11$ & $1.04 \pm 0.07$ \\
\hline $\begin{array}{l}\text { MAP-2 }\left(50 \% \mathrm{CO}_{2} /\right. \\
\left.50 \% \mathrm{O}_{2}\right)\end{array}$ & $0.26 \pm 0.08^{a}$ & $0.34 \pm 0.04^{a}$ & $0.84 \pm 0.16^{b}$ & $1.79 \pm 0.14^{b}$ & $1.96 \pm 0.12^{c}$ & $2.83 \pm 0.24$ & $4.21 \pm 0.19$ \\
\hline
\end{tabular}

Values $(n=3)$ are expressed as mean \pm SD. The values in the same column with various superscript letters reflect the significant difference at $p<0.05$.

et al. (2013), who noted that modified atmosphere and vacuum packaged tilapia fish had the lower MDA in the absence or lower of $\mathrm{O}_{2}$ compared to the control sample. On the other hand, the products packed under MAP-2 in the current study (which contains $50 \%$ of $\left.\mathrm{O}_{2}\right)$ presented higher $(p<0.05)$ TBARS value on day 6,9 , and 12 of storage compared to the control (which contains approximately $21 \%$ of $\mathrm{O}_{2}$ (data not shown)), vacuum and MAP-1 samples (Table 3). Except for the MAP-2, no samples crossed the acceptable limit (2 $\mathrm{mg} \mathrm{MDA} / \mathrm{kg}$ ) over the entire storage time. Similar results were observed for tilapia fillets under control, vacuum, and MAP with $50 \% \mathrm{CO}_{2} / 50 \% \mathrm{~N}_{2}$ conditions at the same storage temperature (Lázaro, Monteiro, \& Conte-Junior, 2020). The MAP-2 $\left(50 \% \mathrm{CO}_{2} / 50 \% \mathrm{O}_{2}\right)$ sample exceeded the limit on and after day 12 of the storage (Table 3 ). The higher amounts of TBARS in the MAP-2 sample may be due to the higher rate of secondary lipid oxidation relative to the other packed samples since it contained a higher amount of $\mathrm{O}_{2}$ (50\%) along with $\mathrm{CO}_{2}$. Ruiz-Capillas and Moral (2001) found similarly higher TBARS amounts for $\mathrm{CO}_{2}^{-}$ enriched packaging systems. It was probably the result of a synergistic reaction between $\mathrm{CO}_{2}$ and $\mathrm{O}_{2}$, which eased the autoxidation of PUFA (Ruiz-Capillas \& Moral, 2001). However, the levels of TBARS may not indicate the actual degree of fat oxidation because MDA may interact with other fish flesh compounds such as amines, nucleic acid and nucleosides, amino acids, proteins, and other aldehydes (Domínguez et al., 2019).

\subsection{Total Viable Count (TVC)}

In the current study, the initial TVC of sliced tilapia was $4.17 \log \mathrm{CFU} / \mathrm{g}$, which indicates an acceptable fresh quality. The bacteria counts of $2-6 \log \mathrm{CFU} / \mathrm{g}$ are considered the satisfactory initial standard of freshly caught freshwater fish reported for tilapia, rainbow trout, silver perch, and sea bass (Gelman, Glatman, Drabkin, \& Harpaz, 2001). This initial TVC value was lower than that of recently studied tropical fishes such as $4.32 \mathrm{log}$ CFU/g for pangasius catfish (Islam et al., 2020), $4.29 \mathrm{log}$ CFU/g for rohu fish (Das et al., 2020), and $5.22 \mathrm{log}$ CFU/g for goonch fish (Alice et al., 2020). With increasing storage time under all treatments, the TVCs of sliced tilapia gradually increased. The TVCs of the control sample quickly raised to 7 log CFU/g within eight days from the initial value. TVCs were initially not significantly influenced by the treatments $(p>0.05)$. However, significantly ( $p$ $<0.05$ ) lower TVCs were found on day 9 and 12 of the storage period in all treatments in comparison to the control (Figure 1). International Commission of Microbiological Specification for Food (ICMSF) (1986) suggested that the TVC value of $7 \log C F U / g$ is recommended for fresh and frozen fish as the upper acceptability limit. The TVCs surpassed the 7 log CFU/ $\mathrm{g}$ on days 6-9 for control, days 9-12 for vacuum, day 12 for MAP-2, and day 15 during the storage period for MAP-1 sample (Figure 1). Based on the acceptable limit of TVC, the shelf life was estimated at 6-9 days for control, $9-12$ days for vacuum package, 12 days for MAP-2, and 15 days for MAP-1 sample. In the previous studies, comparatively lower shelf life for sliced goonch fish (Alice et al., 2020) and higher shelf life for rohu fish (Das et al., 2020) were observed under the same packaging and storage conditions. Lower TVCs of the samples kept under MAP directed that $60 \% \mathrm{CO}_{2}$ effectively inhibited the microbial growth as $\mathrm{CO}_{2}$ shows more effects as an antibacterial agent at a higher concentration (Farber, 1991). The high $\mathrm{CO}_{2}$ levels inhibited psychotropic bacteria's growth during 


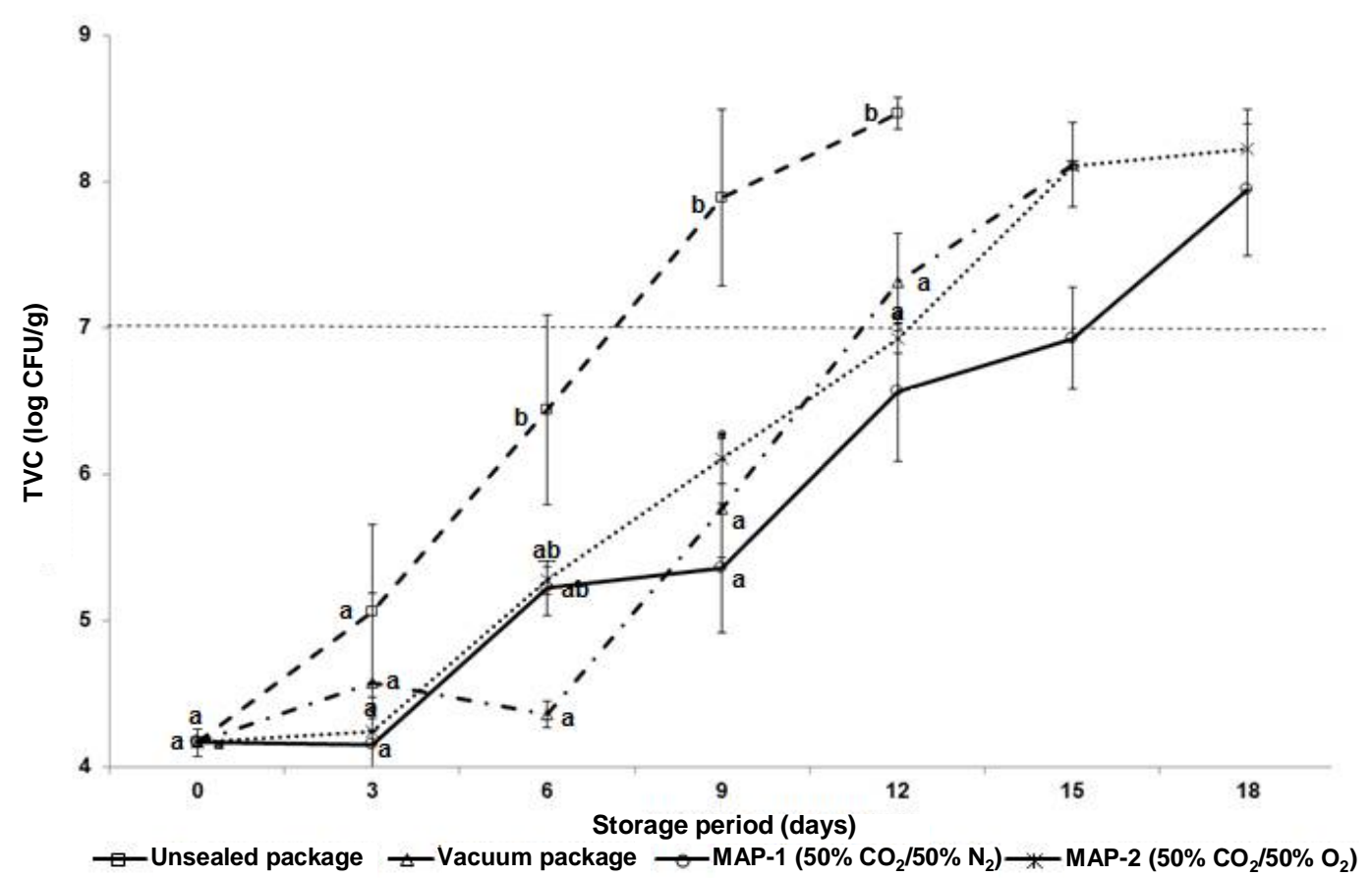

Figure 1. Changes in total viable counts (log CFU/g) of sliced tilapia (Oreochromis niloticus) under vacuum packaging and MAP systems during storage at $4 \pm 1^{\circ} \mathrm{C}$. Values $(n=3)$ are expressed as mean \pm SD. The values on the same day with different letters reflect the significant difference at $p<0.05$

fish storage at low-temperature, indicating the high $\mathrm{CO}_{2}$ sensitivity of those bacteria (Masniyom, Benjama, \& Maneesri, 2011). On the other hand, lower TVCs of samples kept under vacuum packaging compared to that of air indicated that the absence of oxygen could hinder the growth of aerobic spoilage bacteria, predominantly Aeromonas spp. and Pseudomonas spp. (Masniyom et al., 2011). Our result was in agreement with Masniyom et al. (2013), who stated that TVC remained low when tilapia kept in MAP with $60 \% \mathrm{CO}_{2}$. It was also reported that $50 \% \mathrm{CO}_{2}$ inhibited the bacterial growth in chub mackerel (Scomber colias) (Stamatis \& Arkoudelos, 2007), $40 \% \mathrm{CO}_{2} / 30 \% \mathrm{~N}_{2} / 30 \%$ $\mathrm{O}_{2}$ in swordfish (Xiphias gladius) (Pantazi et al., 2008) and $50 \% \mathrm{CO}_{2} / 50 \% \mathrm{~N}_{2}$ in Pangasius hypophthalmus fillets (Noseda et al., 2012) during refrigerated storage.

MAP-1 treatment $\left(50 \% \mathrm{CO}_{2} / 50 \% \mathrm{~N}_{2}\right)$ in the current study showed the highest shelf life (15 days) for tilapia fish, which is similar to that of Masniyom et al. (2013) under MAP $\left(60 \% \mathrm{CO}_{2} / 10 \% \mathrm{O}_{2} / 30 \% \mathrm{~N}_{2}\right)$ at $4{ }^{\circ} \mathrm{C}$. Raising the amount of $\mathrm{CO}_{2}$ in the package from $50 \%$ to $75 \%$ along with $\mathrm{N}_{2}$, the shelf life of ready-to-cook pangas fish curry at $4^{\circ} \mathrm{C}$ increased from 12 to 15 days (Nayma et al., 2020). Reddy, Schreiber, Buzard, Skinner, and Armstrong (1994) recorded a longer shelf life of tilapia fillets ( $>25$ days) in the MAP storage than the current studies of MAP $\left(50 \% \mathrm{CO}_{2} / 50 \% \mathrm{~N}_{2}\right)$ stored at $4^{\circ} \mathrm{C}$. The explanation for this might be the use of a significant amount of carbon dioxide and nitrogen together. Cyprian et al. (2013) recorded a shelf life of packaged tilapia fillets for 23 days under MAP $\left(50 \% \mathrm{CO}_{2} / 50 \%\right.$ $\mathrm{N}_{2}$ ) stored at $1^{\circ} \mathrm{C}$, which is also higher than current research. This result might be due to the difference in storage temperature where the $1^{\circ} \mathrm{C}$ is colder than $4^{\circ} \mathrm{C}$ of the current study. The highest shelf life of 15 days was observed in the case of MAP- $1\left(50 \% \mathrm{CO}_{2} / 50 \%\right.$ $\mathrm{N}_{2}$ ) due to the slightly slower growth of bacteria during the storage period than other packaging systems. MAP-1 created anaerobic conditions within the pack, which reduced the growth of aerobic bacteria and thus increased the shelf life. Also, $\mathrm{CO}_{2}$ has a bacteriostatic effect and prevents oxidative rancidity as well (Farber, 1991).

\subsection{Total Coliforms and Fecal Coliforms}

Total coliform bacteria are usually observed in the aquatic environment, soil, and vegetation, and those are commonly harmless. Fecal coliform bacteria are a type of total coliform bacteria found in the intestines and feces of humans and animals. They are regarded as sanitary index organisms for foods and water. Their presence in the food indicates the probable occurrence of pathogenic bacteria of fecal origin (Li \& Liu, 2019). Total coliforms and fecal coliforms have acceptable limits of $<100$ MPN / g and $<10$ MPN / $g$ for fish and fishery products, respectively (ICMSF, 1986).

In the current study, total coliforms and fecal coliforms showed irregular growth behavior and were unsuccessful in remarking a progressive increase in 
total coliform and fecal coliform counts. There is an agreement with the study of Abelti (2013), who also found irregular growth behavior of total and fecal coliforms while studying ice stored lobsters (Pacifastacus spp). However, the total coliform counts of sliced tilapia fish ranged from $<3$ to $93 \mathrm{MPN} / \mathrm{g}$, and fecal coliform counts ranged from $<3$ to $9.2 \mathrm{MPN} / \mathrm{g}$ under all packaging systems in the 18 days of storage period (data not shown). Total coliform counts were not affected by the treatments in the storage period, which agrees with that of Soccol et al. (2005). However, the total coliforms and fecal coliform counts did not exceed the acceptable limit under all packaging systems, which directed that the samples were taken from a non-polluted area and maintained aseptic conditions throughout the preparation of packaged products by handlers. The low growth of coliforms may have observed because coliforms are mesophilic and, therefore, are hindered by refrigerated storage at $4^{\circ} \mathrm{C}$ (Soccol et al., 2005). It was noted that $\mathrm{CO}_{2}$ more than $50 \%$ delayed coliform growth in tilapia fillets stored under MAP (Reddy, Schreider, Buzard, Skinner, \& Armstrong, 1994).

\section{Conclusion}

The above discussion led to the conclusion that all treatments obtained adequate shelf life during the storage period, except for the control sample showing total bacterial counts crossed the acceptable levels on days 6-9 of the storage. Vacuum packaging extended the shelf life by $9-12$ days. On the other hand, MAP- 1 with $50 \% \mathrm{CO}_{2} / 50 \% \mathrm{~N}_{2}$ extended the shelf life by 15 days and MAP-2 with $50 \% \mathrm{CO}_{2} / 50 \% \mathrm{O}_{2}$ increased the shelf life by 12 days. Therefore, the MAP-1 demonstrated the highest shelf life of sliced tilapia fishes based on bacterial counts. The processors or superstores may use this packaging technology to display the fish and fishery products under refrigeration conditions, which will increase the product's shelf life, value, convenience, and grade.

\section{Acknowledgments}

The research work was funded by the National Agricultural Technology Program Phase-2 (NATP-2) of Bangladesh Agricultural Research Council (BARC) (CRG Sub-project ID-316).

\section{References}

Abelti, A. L. (2013). Microbiological and chemical changes of Nile Tilapia (Oreochromis niloticus L.) fillet during ice storage: effect of age and sex. Advance Journal of Food Science and Technology, 5(10), 1260-1265. doi: 10.19026/ajfst.5.3093
Alfaro, B., Hernández, I., Le Marc, Y., \& Pin, C. (2013). Modelling the effect of the temperature and carbon dioxide on the growth of spoilage bacteria in packed fish products. Food Control, 29(2), 429-437. doi: 10.1016/j.foodcont.2012.05.046

Alice, E. J., Amanullah, M., Karim, M. A., Hossain, M. A., \& Islam, M. T. (2020). Effects of vacuum and modified atmosphere packaging on the biochemical and microbiological quality of sliced goonch fish (Bagarius bagarius) stored at refrigerated condition. Food Research, 4(6), 2256-2264. doi: 10.26656/fr.2017.4(6).287

Amanullah, M. (2019). Evaluation of consumers preference of fresh fish and its packaging in the superstores of Dhaka city (Unpublished master's thesis). Department of Fisheries, University of Rajshahi, Rajshahi, Bangladesh

American Public Health Association (1992). Compendium of methods for the microbiological Examination of foods (3rd ed). Washington DC: American Public Health Association.

Ashie, I. N. A., Smith, J. P., \& Simpson, B. K. (1996). Spoilage and shelf life extension of fresh fish and shellfish. Critical Reviews in Food Science \& Nutrition, 36(1-2), 87-121. doi: 10.1080/ 10408399609527720

Ayala, M. D., Abdel, I., Santaella, M., Martinez, C., Periago, M. J., Gil, F., Blanco, A., \& Albors, O. L. (2010). Muscle tissue structural changes and texture development in sea bream, Sparus aurata L, during post-mortem storage. LWT-Food Science Technology, 43, 465-475. doi: 10.1016/j.lwt.2009.08.023

Binsi, P. K., Shamasundar, B. A., \& Dileep, A.O. (2007). Physico-chemical and functional properties of proteins from green mussel (Perna viridis) during ice storage. Journal of the Science of Food and Agriculture, 87, 245-254. doi: 10.1002/ jsfa.2706

Binsi, P. K., Viji, P., Visnuvinayagam, S., Ninan, G., Sangeeta, G., Triveni, A., \& Ravishankar, C. N. (2015). Microbiological and shelf life characteristics of eviscerated and vacuum packed freshwater catfish (Ompok pabda) during chill storage. Journal of Food Science and Technology, 52(3), 1424-1433. doi: 10.1007/s13197-013-1165-x

Bogard, J. R., Thilsted, S. H., Marks, G. C., Wahab, M. A., Hossain, M. A., Jakobsen, J., \& Stangoulis, J. (2015). Nutrient composition of important fish species in Bangladesh and potential contribution to recommended nutrient intakes. Journal of Food Composition and Analysis, 42, 120-133. doi: 10.1016/j.jfca.2015.03.002

Connell, J. J. (1995). Control of fish quality (4th ed.). Oxford, UK: Wiley-Blackwell.

Cyprian, O., Lauzon, H. L., Johannsson, R., Sveinsdottir, K., Arason, S., \& Martinsdottir, E. (2013). Shelf life of air and modifed atmosphere-packaged fresh tilapia (Oreochromis niloticus) fillets stored under chilled and super chilled conditions. Food Science and Nutrition, 1(2), 130- 140. doi: 10.1002/fsn3.18 
Das, K. C., Alice, E. J., Hossain, M. A., Mehbub, M. F., \& Islam, M. T. (2020). Effects of vacuum and modified atmosphere packaging on the shelf life of Rohu fish (Labeo rohita) stored at refrigerated temperature $\left(4^{\circ} \mathrm{C}\right)$. International Food Research Journal (in press).

DeLong, D. P., Losordo, T., \& Rakocy, J. (2009). Tank culture of tilapia. Stoneville, MS, USA: Southern Regional Aquaculture Center Publication No. 282.

DeWitt, C. A. M., \& Oliveira, A. (2016). Modified atmosphere systems and shelf life extension of fish and fishery products. Foods, 5(3), 48. doi: 10.3390/ foods 5030048

Domínguez, R., Pateiro, M., Gagaoua, M., Barba, F. J., Zhang, W., \& Lorenzo, J. M. (2019). A comprehensive review on lipid oxidation in meat and meat products. Antioxidants, 8(10), 429. doi: 10.3390/ antiox8100429

European Commission (2005). Determination of the concentration of TVB-N in fish and fishery products. Commission Regulation, Chapter III. (EC) No 2074/ 2005. Official Journal of European Union, L37, 338.

Farber, J. M. (1991). Microbiological aspects of modifiedatmosphere packaging technology-a review. Journal of Food Protection, 54, 58-70. doi: 10.4315/0362028X-54.1.58

Food and Drug Administration (2002) Enumeration of Escherichia coli and the coliform bacteria. In P. Feng, S. D. Weagant, M. A. Grant, \& W. Burkhardt (Eds), Bacteriological analytical manual. Washington DC: US Food and Drug Administration.

Gelman, A., Glatman, L., Drabkin, V., \& Harpaz, S. (2001). Effects of storage temperature and preservative treatment on shelf-life of the pond-raised freshwater fish, silver perch (Bidyanus bidyanus). Journal of Food Protection, 64, 1584-1591. doi: 10.4315/0362028X-64.10.1584

Gonzales, Jr. J. M., \& Brown, P. B. (2006). Nile tilapia Oreochromis niloticus as a food source in advanced life support systems: Initial considerations. Advances in Space Research, 38 (6), 1132-1137. doi: 10.1016/ j.asr.2005.11.002

Gupta, M. V., \& Acosta, B. O. (2004). A review of global tilapia farming practices. Aquaculture Asia, IX(1), 712.

International Commission of Microbiological Specification for Food (1986). Microorganisms in food2, Sampling for microbiological analysis: Principles and Specific Applications ( $2^{\text {nd }}$ ed.). Toronto: University of Toronto Press.

Islam, M. T., Alice, E. J., Saha, S., Karim, M. A., Amanullah, M., Rahman, M., \& Chowdhury, P. (2020). Shelf-life of vacuum and modified atmosphere packaged sliced pangasius catfish (Pangasianodon hypophthalmus) under refrigerated storage condition. Bangladesh Journal of Fisheries, 32(1), 73-82.

Lázaro, C. A., Monteiro, M. L. G., \& Conte-Junior, C. A. (2020). Combined effect of modified atmosphere packaging and UV-C radiation on pathogens reduction, biogenic amines, and shelf life of refrigerated tilapia (Oreochromis niloticus) Fillets. Molecules, 25(14), 3222. doi: 10.3390/ molecules25143222

Li, D., \& Liu, S. (2019). Water quality monitoring in aquaculture. In Water quality monitoring and management: Basis, technology and case studies. Cambridge, UK: Academic Press.

Li, D., Li, Q., Zhang, Y., Liu, X., Hong, H., \& Luo, Y. (2017). Quality changes and microbiological spoilage analysis of air packed and vacuum packed silver carp (Hypophthalmichthys molitrix) fillets during chilled storage. Journal of Food Process Preservation, e13389. doi: 10.1111/jfpp.13389

Lines, J. A., \& Spence, J. (2012). Safeguarding the welfare of farmed fish at harvest. Fish Physiology and Biochemistry, 38(1), 153-162. doi: 10.1007/s10695011-9561-5

Masniyom, P., Benjama, O., \& Maneesri, J. (2011). Extending the shelf-life of refrigerated green mussel (Perna viridis) under modified atmosphere packaging. Songklanakarin Journal of Science and Technology, 33, 171-179.

Masniyom, P., Benjama, O., \& Maneesri, J. (2013). Effect of modified atmosphere and vacuum packaging on quality changes of refrigerated tilapia (Oreochromis niloticus) fillets. International Food Research Journal, 20(3), 1401-1408.

Metin, S., Erkan, N., Varlik, C., \& Aran, N. (2001). Extension of shelf-life of chub mackerel (Scomber japonicus Houttuyn 1780) treated with lactic acid. European Food Research and Technology, 213(3), 174-177. doi: $10.1007 / \mathrm{s} 002170100362$

Nagarajarao, R. C. (2016). Recent advances in processing and packaging of fishery products: $A$ review. Aquatic Procedia, 7, 201-213. doi: 10.1016/ j.aqpro.2016.07.028

Narasimha Rao, D., \& Sachindra, N. M. (2002). Modified atmosphere and vacuum packaging of meat and poultry products. Food Reviews International, 18(4), 263-293. doi: 10.1081/FRI-120016206

Nayma, K., Das, K. C., Alice, E. J., Mehbub, M. F., \& Islam, M.T. (2020). Extension of shelf-life of ready-to-cook (RTC) pangas fish (Pangasianodon hypophthalmus) curry by modified atmosphere packaging at chilled storage. IOP Conference Series: Earth and Environmental Science, 414, 01201. doi: 10.1088/ 1755-1315/414/1/012015

Noseda, B., Islam, M. T., Eriksson, M., Heyndrickx, M., Reu, K. D., Langenhove, H. V., \& Devlieghere, F. (2012). Microbiological spoilage of vacuum and modified atmosphere packaged Vietnamese Pangasius hypophthalmus fillets. Food Microbiology, 30 (2), 408-419. doi: 10.1016/j.fm.2011.12.025

Pantazi, D., Papavergou, A., Pournis, N., Kontominas, M. G., \& Savvaidis, I. N. (2008). Shelf-life of chilled fresh Mediterranean swordfish (Xiphias gladius) stored under various packaging conditions: microbiological, biochemical and sensory attributes. Food Microbiology, 25, 136-143. doi: 10.1016/ j.fm.2007.06.006 
Park, S. Y., Yoo, S. S., Uh, J. H., Eun, J. B., Lee, H. C., Kim, Y. J., \& Chin, K. B. (2007). Evaluation of lipid oxidation and oxidative products as affected by pork meat cut, packaging method, and storage time during frozen storage $\left(10^{\circ} \mathrm{C}\right)$. Journal of Food Science, 72(2), C114-C119. doi: 10.1111/j.1750-3841.2006.00265.x

Reddy, N. R., Schreider, C. L., Buzard, K. S., Skinner, G. E., \& Armstrong, D. J. (1994). Shelf life of fresh tilapia fillets packaged in high barrier film with modified atmospheres. Journal of Food Science, 59 (2), 260 264. doi: 10.1111/j.1365-2621.1994.tb06943.x

Ruiz-Capillas, C., \& Moral, A. (2001). Residual effect of $\mathrm{CO}_{2}$ on hake (Merluccius merluccius L.) stored in modifed and controlled atmospheres. European Food Research Technology, 212, 413-420. doi: $10.1007 / \mathrm{s} 002170000270$

Soccol, M. C. H., \& Oetterer, M. (2003). Use of modified atmosphere in seafood preservation. Brazilian Archives of Biology and Technology, 46(4), 569-580. doi: $10.1590 / \mathrm{S} 1516-89132003000400011$

Soccol, M. C. H., Oetterer, M., Gallo, C. R., Spoto, M. F., \& Biato, D. O. (2005). Effects of modified atmosphere and vacuum on shelf life of tilapia (Oreochromis niloticus) fillets. Brazilian Journal of Food Technology, 8(1), 7-15.
Stamatis, N., \& Arkoudelos, J. (2007). Quality assessment of Scombercolias japonicas under modified atmosphere and vacuum packaging. Food Control, 18(4), 292-300. doi: 10.1016/j.foodcont.2005.10. 009

Sveinsdottir, K., Martinsdottir, E., Hyldig, G., \& Sigurgisladottir, S. (2010). Sensory characteristics of different cod products. Journal of Sensory Studies, 25, 294-314. doi: 10.1111/j.1745-459X.2009. 00259.x

Velu, S., Abu Bakar, F., Mahyudin, N. A., Saari, N., \& Zaman, M. Z. (2013). Effect of modified atmosphere packaging on microbial flora changes in fishery products. International Food Research Journal, 20(1), 17-26.

Verbeke, W., \& Vackier, I. (2004). Individual determinants of fish consumption: application of the theory of planned behaviour. Appetite, 44(1), 67-82. doi: 10.1016/j.appet.2004.08.006

Wu, T. H., \& Bechtel, P. J. (2008). Ammonia, dimethylamine, trimethylamine, and trimethylamine oxide from raw and processed fish by-products. Journal of Aquatic Food Product Technology, 17, 2738. doi: 10.1080/10498850801891140 